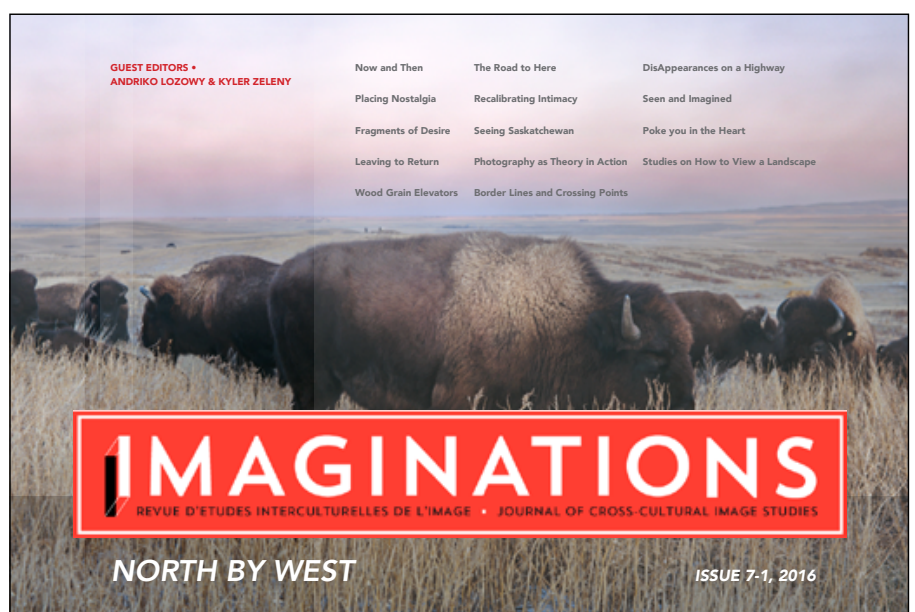

IMAGINATIONS

JOURNAL OF CROSS_CULTURAL IMAGE STUDIES |

REVUE D'ÉTUDES INTERCULTURELLES DE L'IMAGE

Publication details, including open access policy

and instructions for contributors:

http://imaginations.csj.ualberta.ca

\section{North By West}

Editorial Team: Brent Ryan Bellamy, Daniel Laforest, Andriko Lozowy,

Tara Milbrandt, Carrie Smith-Prei, Sheena Wilson

November 23, 2016

\section{To cite this article:}

Smith, Trudi Lynn, and Engle, Karen. "Fragments Of Desire." Imaginations 7:1 (2016): Web (date accessed) 42-51. DOI: 10.17742/IMAGE.NBW.7-1.4
To link to this article:

http://dx.doi.org/10.17742/IMAGE.NBW.7-1.4

The copyright for each article belongs to the author and has been published in this journal under a Creative Commons Attribution NonCommercial NoDerivatives 3.0 license that allows others to share for non-commercial purposes the work with an acknowledgement of the work's authorship and initial publication in this journal. The content of this article represents the author's original work and any third-party content, either image or text, has been included under the Fair Dealing exception in the Canadian Copyright Act, or the author has provided the required publication permissions. 
As soon as the idea of a debt to the dead, to people of flesh and blood to whom something really happened in the past, stops giving documentary research its highest end, history loses its meaning. Paul Ricoeur (qtd. in Merewether 68)
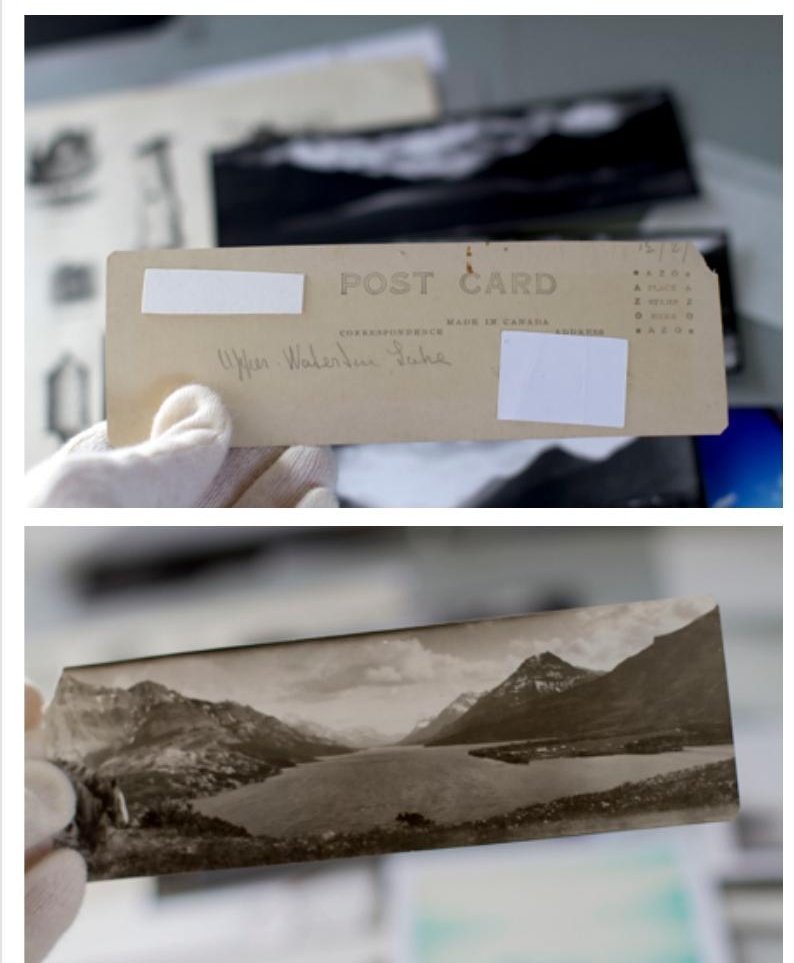

$\mathrm{F}$ H. "Bert" Riggall (1884-1959) took photographs. He was also a "mountain guide, outfitter, hunter, trapper, rancher, naturalist...writer and gunsmith/ loader in southern Alberta" (Fonds Whyte). Sometime in the early 1900s, Riggall photographed Waterton Lake from the Prince of Wales Hotel. He used a Kodak Panoram No. 1 to record this serene view of a lake bounded on either side by mountains, thus producing a now-classic picturesque vision of the Canadian landscape as uninhabited and majestic. ${ }^{3}$ Grazing horses on the far left-presumably members of Riggall's party-constitute the only sign of life here beyond the vegetal. The copy of Russell's image in Trudi Lynn Smith's archive is in the form of a postcard-that classic structure perfecting the miniaturization of experience.
Picture postcards were at the height of their popularity in the early-20th century. For an imperial power such as Britain (and Canada as inheritor of its visual traditions), the picture postcard functioned as a carrier of national mythology (see Engle; Wollaeger; Wong).

Smith found the picture postcard in the archives of the Whyte Museum of the Canadian Rockies. ${ }^{4}$ She placed the card, all alone, in a file labeled "Waterton Lakes National Park (1895 - 2015) - early 20th century photographs - FH (Bert) Riggall - Kodak Panoram No 1." She must have seen so many images in these Whyte archives, but somehow all manner of things converged for her with "Bert" - the shape of the clouds that day, her fatigue, the sound of the wind through the trees...-and she chose his vision as her object. ${ }^{5}$ She becomes Riggall's ghost, haunting his process in a quest to reproduce the photograph he made over 100 years before. ${ }^{6}$

Fig. 1. Panoram by Frederick Herbert (Bert) Riggall,

in collection/courtesy Trudi Lynn Smith 


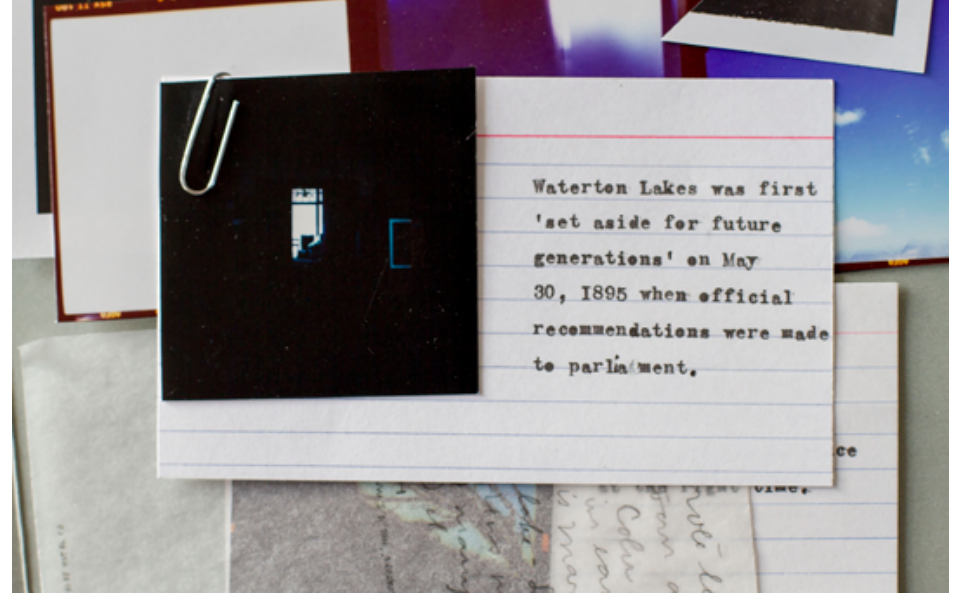

Fig. 2. Trudi Lynn Smith, interior

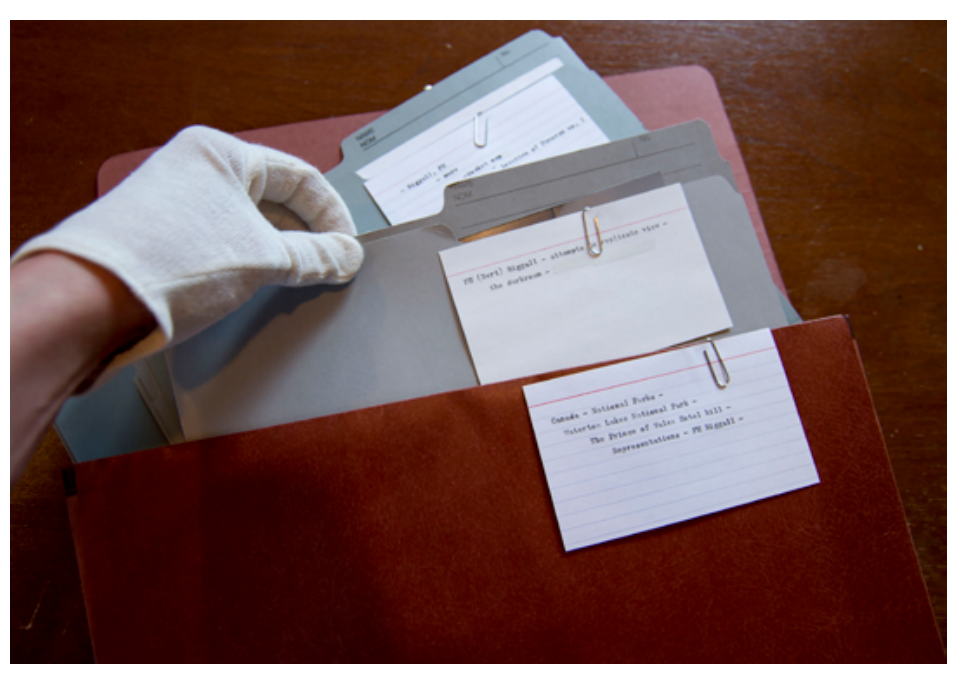

The file folder is labeled with these words-clouds erasure-on an index card paper-clipped to the folder. 1 Inside this file, I find a piece of tracing paper made to look like a postcard, several photographs of varying sizes made from different cameras, and four pieces of photographs that have been cut and orphaned from their contexts-tiny fragments sliced from one environment and laid into this one.7 Among the ephemera, an index card is paper-clipped to a small, square image consisting almost entirely of an inky, interior darkness. Details of the room are vague at best, but in the centre of the photograph, seemingly very far away from the camera, a rectangular window beckons. Yet the window does not open onto any discernible vista-it is backlit by a light so opaque it may as well be black. The light refuses its essential function and shuts out all clues to the outside. Shooting from an impalpable interior, the photographer directs her focus outward to a window that appears too distant to reach, almost like a portal to another time that eternally recedes. Trapped inside the darkness of the present moment, she cannot get close enough to see beyond this stain of light.

Fig. 4. Trudi Lynn Smith, files

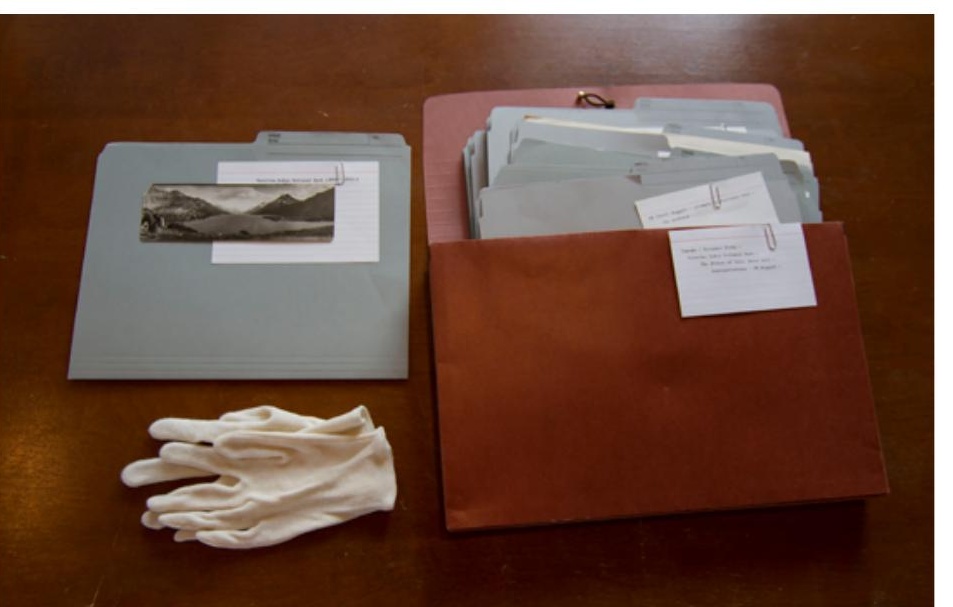

Typed on the index card to the right of the image is the following text: "Waterton Lakes was first 'set aside for future generations' on May 30, 1895 when official recommendations were made to parliament." The caption invokes time. Past and future intermingle in text generated by an actual typewriter, a technology now distant enough to appear archaic. Having all but vanished from contemporary practice, the typewriter is entirely foreign to my students. If a machine I used 30 years ago is too distant for memory, what is 1895 to the future-nows? 

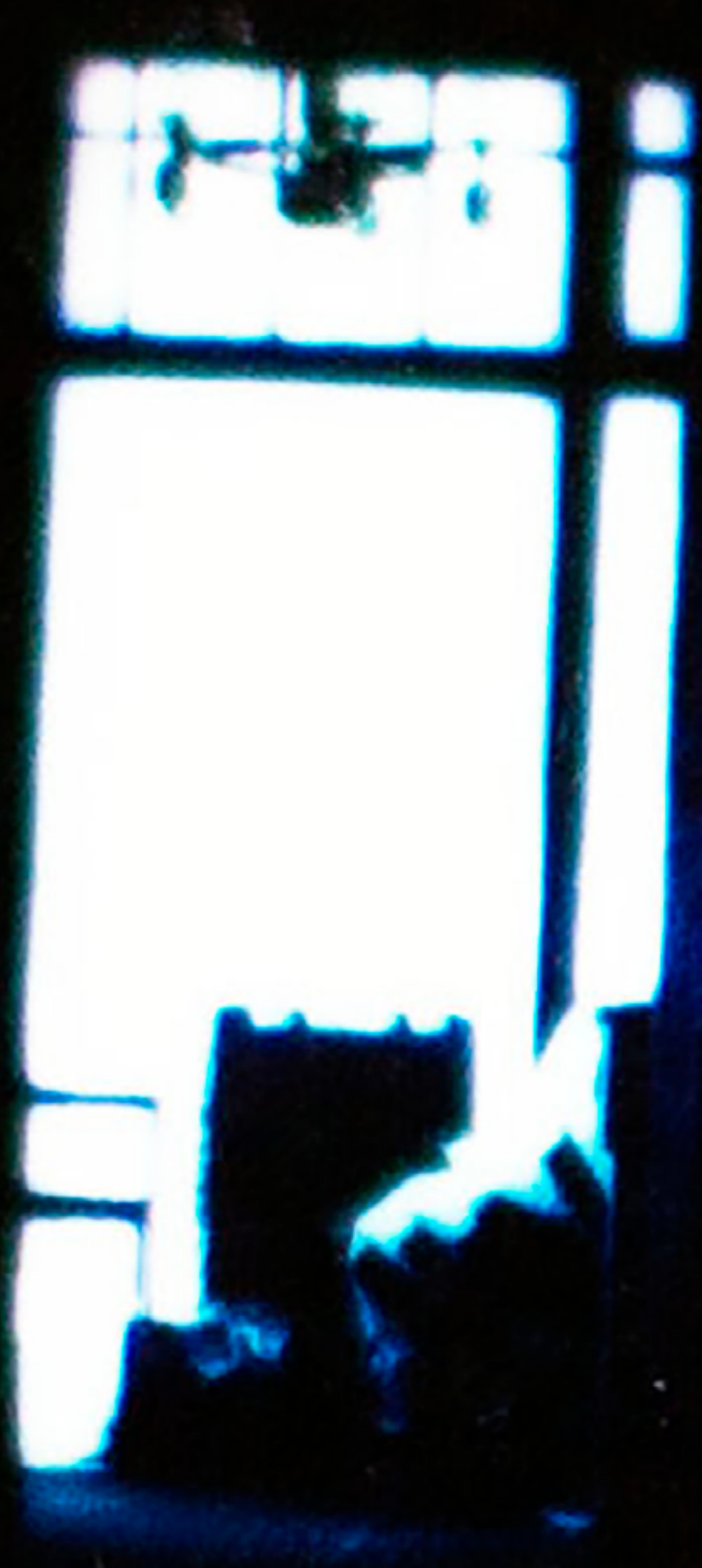

I think of W.G. Sebald's Austerlitz (2001), in which photographs appear amidst narrative without any explicit connections made between them. They sit as silent interruptions in Austerlitz's quest to retrace history. The images are suggestive, but in the end they give up nothing to the reader who is destined to remain just outside the narrator's experience. What does the establishment of Waterton Lake National Park have to do with this inky room?

At first I think that light is the aim of this image, that the photographer evokes the struggle to escape the blackness of the interior through the "light-writing" of technological reproduction. Yet as I continue to look back and forth between window and caption, I begin to picture the photographer setting up camp for an extended stay inside this darkened room. She is not trying to escape into the light; she knows that light is blinding and deceptive. She has learned, as Walter Benjamin learned, that light is a trickster (Benjamin, "Little History"). ${ }^{8}$
Fragility

he sent it by post. I came home one day to find a box hand-delivered, containing a selection of 10 files from her archive. On the front of each file she has attached, with a paperclip, an index card containing a few typed phrases guiding the viewer as to each file's contents. These indexical phrases are more or less concrete. For example, "FH (Bert) Riggall - attempts to replicate view - the darkroom -" reproduces a conventional labeling system in which the index refers quite literally to the file's contents, copies of her multiple attempts to reproduce Riggall's photograph. Other titles follow a less linear logic. "Waterton - the Nondescript" provides no semantic clues to the images and ephemera contained within: photographs of photographs, a piece of tracing paper with what seems to be an impression of the mountains surrounding Waterton Lake, and all manner of index cards attached to small photographs marking different moments from her quest and her haunting of his trajectory. To say that she has sent me multiple narratives is insufficient, for she has done much more with this box. She has generated an infinite number of ways this story can be told, for each folder opens up to a different starting point and branches off into any number of histories, memories, and musings. I start to think of the box as a shell for a living nervous system, one that can generate new synaptic connections with each combination and recombination of its elements. As in Chris Ware's Building Stories, the brilliant box of 

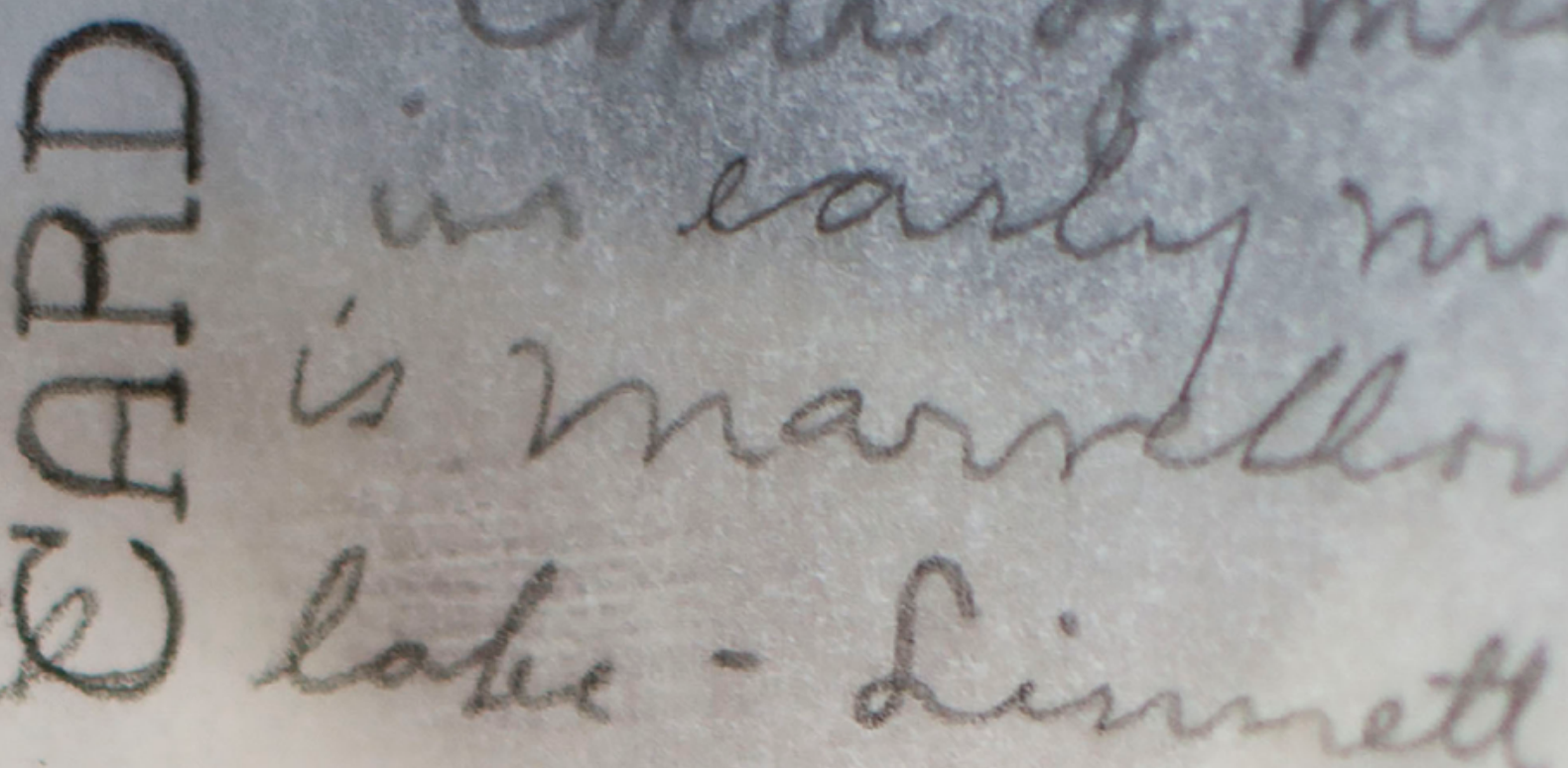

multiple individual fragments of stories that combine and recombine to form related but unique narratives, one chooses a starting point in Smith's archive without any context for the implications of that choice. ${ }^{9}$ The stories that different readers begin to assemble contain the same elements but differ in focus and perspective. These are not puzzle pieces that fit together, but rather fragments of an unfulfilled desire that, in its failure to be realized, indicates the pure contingency of a moment archived as history.

... each folder opens up to a different starting point and branches off into any number of histories, memories, and musings.

Fig. 6. Trudi Lynn Smith, postcard 


\section{Postcard}

Inside the file

\section{clouds}

erasure

$\mathrm{I}$

find a piece of tracing paper she has

turned into a postcard. She has in1 scribed with pencil all the usual elements: a dividing line between address and message spaces; the word POSTCARD (which reminds me of Magritte's insistence that ceci nest pas un pipe $e^{10}$ ); a small rectangle in the upper right-hand corner indicating the place for a stamp; and a tiny caption printed neatly along the side that refers to an absent image. The sender's message reads: "note little town at right colour of $\mathrm{mts}$ in early morning is marvellous [sic] a small lake - Linnett - is near - [indiscernible] me - fed by springs many birds around it."
Two observations about this gossamer object: the absence of the traditional recto/verso structure-she has superimposed the verso on to the recto-and the neatly printed caption, CANADIAN ROCKIES HOTEL CO., references a non-existent photograph, a sign with no referent. The superimposition of front and back shows the entanglement of public with private, national visions with personal messages, and mass production with singular experience (see Derrida, "The Post Card"; Engle 54). The absent image implies a process of abstraction: something material and tangible has been taken away. This blank square on the tracing paper is not merely empty space; it marks a removal so apparently complete as to leave nothing but a ghostly whiteness behind. The caption suggests that the missing image is most likely a reproduction of a devotedly touristic space, the Prince of Wales Hotel on Waterton Lake, since this hotel sits on the same hill as Riggall's and Smith's photographs. The hotel promises an experience of the classically picturesque:

A true historic icon, the Prince of Wales Hotel offers an experience like no other. Views from the hotel lobby and lawn are magnificent panoramas of Waterton Lake and the surrounding mountains. The Prince of Wales Hotel is the perfect place to escape the everyday and immerse yourself in the magic of the mountains and the history of Waterton Lakes National Park. ("Prince of Wales Hotel") 11
Beyond the observation that these views seem to exist to be consumed, the everyday is also pictured as alien to this lovely scene. The deep irony in the hotel's ad copy-that tourists can experience history here while leaving behind their ordinary everyday-is of course the fact that this place had been a location for an indigenous everyday for at least 10,000 years before contact (Reeves, "Native Peoples" 39). The hotel's existence is premised upon the abstraction of all this ordinary business of survival.

Did Riggall travel with the Niitsitapi? ${ }^{12}$ Did he ask them to step aside so they were outside of the frame, or did he just not see them as part of the world he was recording? The orphaned caption forces us to confront the absence of what we expect and know to be present. It asks us to imagine a different picture of the national landscape. ${ }^{13}$ 


\section{Dis-orientation}

$\mathrm{I}$

count at least 31 attempts at replication in this selection of files, though she notes on the back of one of these Polaroids that she had, by August 3rd 2008, made 49 photographs. She keeps a record for most of these pictures, sometimes noting only the date and other times listing weather conditions, exposure number, siting clues, and the occasional feelings of frustration, despair, and tedium. On August 3rd, 2008, she writes on the back of exposure 10:

Here is the thing. There's no viewfinder on the camera, really, so I've been learning about it-moving, pointing, exposing the film, walking to the research house, developing the film, going for coffee while it dries, scanning it, overlaying it with a scan of the original, making calculations, going back, walking up the hill, shooting more photos. They all look like it, none look like it. Riggall apparently had a tripod threading for the camera on his saddle horn. Failure provides openings, all the otherwise begin to take shape.

She follows him-obsessively, compulsively. She uses parallax to stand in his shadow and see through his eyes, but what she learns from parallax is impossibility. ${ }^{14}$ The reasons for this are both concrete and abstract. First, the concrete: the town has grown in size; the snow in Riggall's picture has melted away; erosion has altered the shape of the hill; and trees have come and gone. ${ }^{15}$ As markers of climate change and human

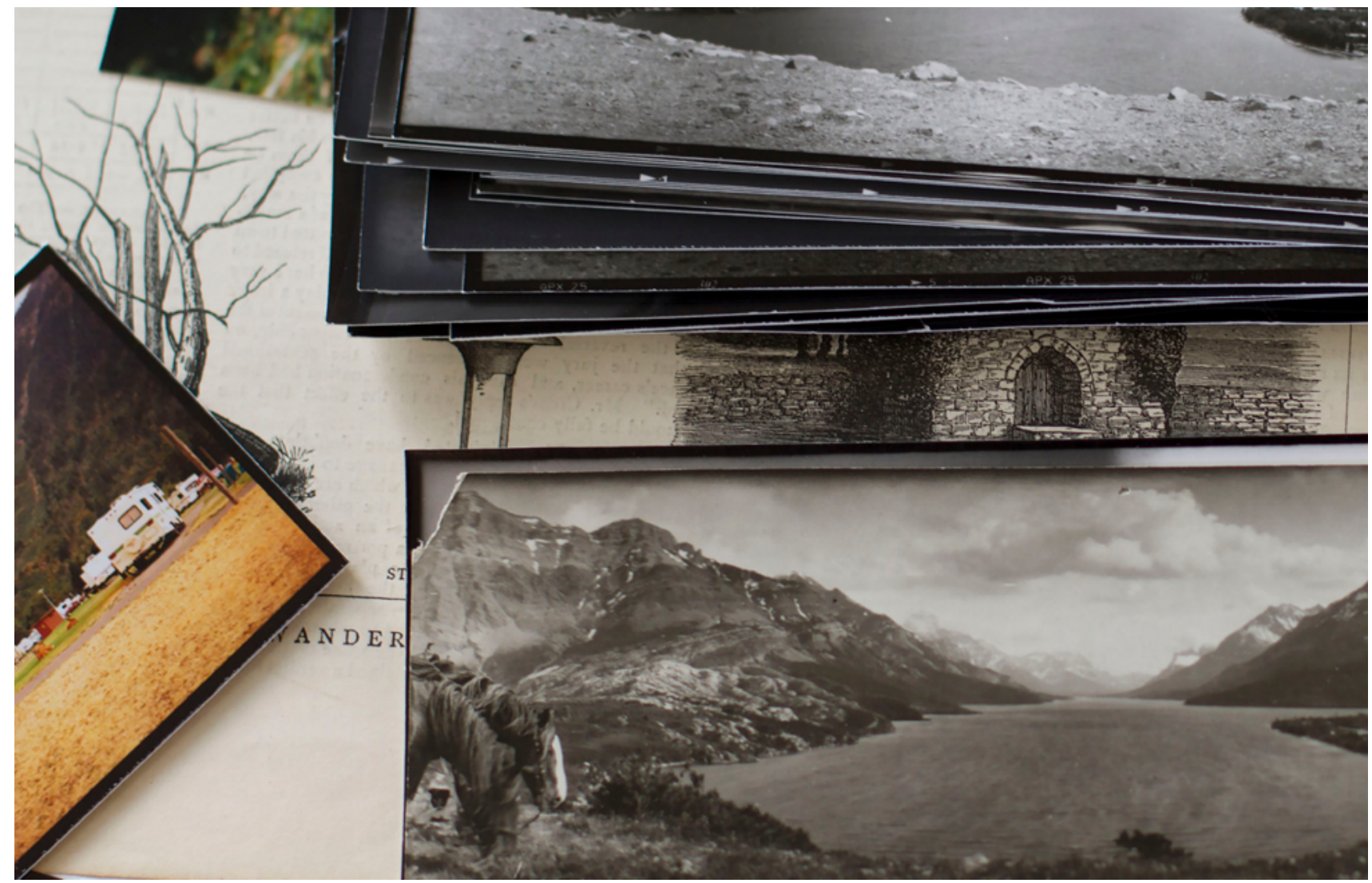

Fig. 7. Trudi Lynn Smith, interior

intervention, the environmental shifts are significant clues for measuring all the material reasons she will never replicate Riggall's photograph. Philosophically, however, Slavoj Žižek reminds us that with parallax, 'the observed difference is not simply 'subjective, due to the fact that the same object which exists 'out there' is seen from two different stations, or points of view. It is rather that...subject and object are inherently 'mediated', so that an 'epistemological' shift in the subject's point of view always reflects an 'ontological' shift in the object itself" (17). She cannot see through his eyes. Riggall saw himself in every picture he made, just as she sees herself in each attempt at replication. In her eyes, he will always be spectral and her Waterton will vibrate with all of the histories that he could not picture. ${ }^{16}$ 


\section{Notes}

${ }^{1}$ I write this during a transitional moment in Canadian political history. Justin Trudeau and the Liberal Party have just been elected to a majority government, ousting Stephen Harper and the Conservative Party of Canada from over 8 years of governing. While this election is seemingly unrelated to the essay I am writing here, the issues addressed here regarding the history of photography and the colonial imagination in Canada have become inextricably entwined with the former Harper government's practices of information management. As Anne Kingston details in her Maclean's article, "Vanishing Canada: Why We're All Losers in Ottawa's War on Data," the Harper government's commitment to destroying data and historical records has produced an utterly bizarre contemporary situation in which entire communities are no longer represented-a disaster for policy-making-and researchers will be unable to undertake comparative, longitudinal studies (September 18 , 2015). Repeat photography, the method undertaken by Smith in this project, is only possible so long as archives are preserved. Despite the selective and exclusionary nature of any archive, they are a crucial resource through which writers and artists can re-imagine history. I write today with a tentative sense of hope, and while the future may prove me naïve, this hope has also inflected the way I understand Trudi Lynn Smith's project of using photography to show us a different view of Waterton National Park.

2 Throughout this essay, "her" and "she" refer to Trudi Smith, visual anthropologist and artist. See: http://trudilynnsmith. $\mathrm{com} /$ for more information on her work.
3 The convention of picturing Canada as so many "landscape paintings" comes from English imperial traditions and must be understood in the context of the emergence of national parks as supposed zones of protection (Smith, "The Anthropology" 125). As so many scholars have noted, the identity of national parks relies upon a colonial and racist notion of the land as pristine and uninhabited. The pictures generated by 19th- and early-20th-century explorers of the land were fundamental to solidifying this myth and its dissemination through generations of settler Canadians (Smith, "The Anthropology" 125).

4 Smith first saw the image at the Whyte Museum and again, later, at the Pincher Museum. A friend, however, sent the postcard copy that is in her archive. Thanks to Smith for this clarifying detail.

5 See Kathleen Stewart's discussion of ordinary affects as "Something throws itself together in a moment as an event and a sensation; a something both animated and inhabitable.... [They are] moving things-things that are in motion and that are defined by their capacity to affect an to be affected-they have to be mapped through different coexisting forms of composition, habituation, and event" (1 4; original emphasis)

6 The reproduction includes the equipment she uses: "I arrange with his grandson to use the exact camera that Riggall shot this photograph with, the Kodak Panoram No. 1" (Smith, "Field Notes 2008"). The irony of being unable to reproduce a photograph she finds on a picture postcard (an item of mass reproduction) with technology designed for reproduction is noteworthy.
${ }^{7}$ As Derrida writes, "This structural possibility of being severed from its referent or signified...seems to me to make of every mark...the nonpresent remaining of a differential mark cut off from its alleged 'production of origins"” ("Signature Event Context" 318). These tiny fragments perform heavy labour for the archive. They are visual indicators of what I understand as a complex critique of origins. Using photography-that technology of reproduction that dissolves the notion of an original-Smith severs fragments from an unknown set of lost originals that began their life as copies (Benjamin, "The Work of Art"). Moreover, she does not provide us with pieces that can be put back together to make a clear picture. Instead, we are left with nothing but shards that look like nothing at all, the remains of one (or several) original copy (or copies). These four tiny pieces generate an aporia through which we must travel in order to assemble any picture of history.

8 Smith's inky interior is akin to the only colour photograph Barthes uses in Camera Lucida (1980), Daniel Boudinet's Polaroid (1979) —an image that asks us to meditate on darkened interiors and what the light may or may not reveal.

${ }^{9}$ As Douglas Wolk describes in his review of Building Stories, "You will never be able to read 'Building Stories' on a digital tablet, by design. It is a physical object, printed on wood pulp, darn it. It's a big, sturdy box, containing 14 different 'easily misplaced elements'-a hard-bound volume or two, pamphlets and leaflets of various dimensions, a monstrously huge tabloid à la century-old Sunday newspaper comics sections and a folded board of the sort that might once have come with a fancy game. In which order should one read them? Whatever, Ware shrugs, uncharacteristically relinquishing his customary absolute control. In the world of 'Building Stories', linearity leads only to decay and death" ("Inside the Box"). 
10 Magritte's infamous semiotic joke shows us how reproductions never give access to the thing itself. Smith's pseudo postcard, rendered on the most delicate of tracing paper, suggests the fragility of her quest to reproduce Riggall's photograph and the ultimate impossibility of occupying his exact position. It is a wonderful miniaturization of the challenges involved in historiographic work.

${ }^{11}$ Since the initial writing of this essay, the website text has been modified.

12 As Reeves details: "Intensive archaeological research in Waterton Lakes National Park has demonstrated a long and essentially continuous record of Native occupation extending back some 10,000 years" ("Ninaistákis" 291)

13 Smith reminds us that "Absences count as much as presences...Survey photography is not close-up views of geological detail, portraits of people you know, indigenous guides or existing pathways. While their photography denied these possibilities through omission, the surveyors encountered more than they recorded... These political implications of photographic visuality deny the very access points that made the views possible" (The Anthropology of Historical Photography" 126-27)

\section{Works Cited}

14 Smith explains: "Most repeat photographers take advantage of parallax, the apparent motion of an object against a background due to a change in observer position, in order to site their cameras" ("Repeat Photography" 197-98).

15 These are all penciled notations on top of an exposure from July 29th, 2008.

16 This relation of spectrality is analogous to Derrida's description of the archive: "the structure of the archive is spectral...neither present nor absent 'in the flesh'...a trace always referring to another whose eyes can never be met..." ("Archive Fever" 89). The methodology of this essay is intended to reflect both the fragmentary and spectral structure of Smith's project.
Barthes, Roland. Camera Lucida: Reflections on Photography. Trans. Richard Howard. New York: Hill and Wang, 1982. Print.

Benjamin, Walter. "Little History of Photography." Walter Benjamin: Selected Writings, Volume 2: Part 2: 1931-1934. 2003. Eds. Michael W. Jennings, Howard Eiland and Gary Smith. Cambridge, Mass: Belknap Press, 2005. 507-530. Prin

---. "The Work of Art in the Age of Its Technological Reproducibility." Walter Benjamin: Selected Writings, Volume 4: 1938-1940. Eds. Michael W. Jennings, Howard Eiland and Gary Smith. Cambridge, Mass: Belknap Press, 2003. 251283. Print.

Derrida, Jacques. Archive Fever: A Freudian Impression. 1995. Trans. Eric Prenowitz. Chicago: University Of Chicago Press, 1998. Print.

---. "Signature Event Context." Margins of Philosophy. Trans. Alan Bass. Reprint edition. Chicago: University Of Chicago Press, 1984. 307-330. Print

---. The Post Card: From Socrates to Freud and Beyond. Trans. Alan Bass. Chicago: University Of Chicago Press, 1987. Print.

Engle, Karen. Seeing Ghosts: 9/11 and the Visual Imagination. Montreal: McGill-Queens University Press, 2009. Print.

"Fonds Whyte - 1106 - Bert Riggall Fonds." Alberta on Record. Archives Society of Alberta, n.d. Web. 13 Dec. 2015 


\section{Image Notes}

Kingston, Anne. "Vanishing Canada: Why We're All Losers in Canada's War on Data." Macleans.ca. N.P., 18 Sept. 2015. Web. 13 Dec. 2015.

Merewether, Charles, ed. The Archive. 1st edition. Cambridge, Mass: The MIT Press, 2006. Print.

Prince of Wales Hotel in Waterton Park | Glacier Park Inc. N.p., n.d. Web. 13 Dec. 2015.

Reeves, Brian. "Native Peoples and Archaeology of Waterton Glacier International Peace Park." Sustaining Rocky Mountain Landscapes: "Science, Policy, and Management for the Crown of the Continent Ecosystem." Eds. Tony Prato and Dan Fagre. Washington, DC: Routledge, 2007. 39-54. Print

--. "Ninaistákis - the Nitsitapii’s Sacred Mountain Traditional Native Religious Activities and Land Use/ Tourism Conflicts." Sacred Sites, Sacred Places. Ed. David Carmichael, et al. London: Routledge, 1994. 265-294. Print.

Sebald, W. G. Austerlitz. Toronto: Vintage Canada, 2002. Print.

Smith, Trudi Lynn. Field Notes 2008: Tracker. N.p., n.d. Web. 13 Dec. 2015

---. "Repeat Photography as a Method in Visual Anthropology." Visual Anthropology 20.2/3 (2007): 179-200. Print.

---. “The Anthropology of Historical Photography in a Protected Area: Life and Death in Waterton Lakes Nationa Park, Alberta." Anthropologica 56.2 (2014): 117-133. Print.
Stewart, Kathleen. Ordinary Affects. Durham, NC: Duke University Press, 2007. Print.

Ware, Chris. Building Stories. Box Pack edition. New York: Pantheon, 2012. Print.

Wolk, Douglas. "Inside the Box: 'Building Stories,' by Chris Ware.” New York Times. 18 Oct. 2012. Web. 21 July 2016.

Wollaeger, Mark. Modernism, Media, and Propaganda: British Narrative from 1900 to 1945. Princeton University Press, 2008. Print.

Wong, Yoke-Sum. "Beyond(andBelow)Incommensurability." Common Knowledge 8.2 (2002): 333-357. Print.

Žižek, Slavoj. The Parallax View (Cambridge: MIT Press, 2006). Print.
All images Trudi LynnSmith. 